\title{
Impact of Photovoltaic Tied to Electrical Grid System on Power Quality
}

\author{
Salah Kamal EL-Sayed, Ehab Issa Okasha \\ Department of Electrical Power \& Machines, Faculty of Engineering, Al-Azhar University, Cairo, Egypt \\ Email address: \\ Salah_kama11982@yahoo.com (S. K. EL-Sayed), ehab_okasha2011@yahoo.com (E. I. Okasha) \\ To cite this article: \\ Salah Kamal El-Sayed, Ehab Issa Okasha. Impact of Photovoltaic Tied to Electrical Grid System on Power Quality. Journal of Electrical and \\ Electronic Engineering. Vol. 5, No. 2, 2017, pp. 23-32. doi: 10.11648/j.jeee.20170502.11
}

Received: March 8, 2017; Accepted: March 17, 2017; Published: April 4, 2017

\begin{abstract}
The High Penetration of PV power into the existing electricity grid needs more study and analysis to enable safe operation. One of the major concerns is the impact of PV system on grid power quality .Poor power quality could cause disturbance and financial losses due to the use of power inverters. Harmonic distortion is a serious power quality problem that reduces power quality and consequently causes a number of problems to consumer and network. This Paper proposes a new strategy for power quality improvement in a three-phase grid connected PV Inverter with central and string configuration and controlling on them using Sinusoidal pulse width modulation and space vector modulation methods with LCL Filter . This paper investigates PV Inverter configuration and impact of them on PV Plant Performance and harmonics that produced by PV inverter. The design, modeling, and analysis of a grid-tied PV system were performed in the PSCAD software simulation environment. The simulations of Harmonic Distortion (Total Demand Distortion \& Total Harmonic Distortion) were applied at Point of Coming Coupling and the results obtained were compared with the limits specified by IEEE STD 519-1992 standards.
\end{abstract}

Keywords: Harmonics, Photovoltaic, PSCAD

\section{Introduction}

Due to increases in energy demand, fossil fuel problems such as fossil fuel depletion, $\mathrm{CO}_{2}$ emissions and the use of solar energy is growing fast. This Paper Studies the effect of photovoltaic tied to Electric grid System on the power quality under weather conditions of Egypt by using realistic temperatures and solar irradiance data from The ASHRAE International Weather for Energy Calculation. Also, this Paper investigates the impact of PV Inverter Configuration (Central and String) with different controlling methods on inverter such as (Sinusoidal Pulse width Modulation and Space vector Modulation) from point of view PV plant efficiency and Electric Grid Quality. A Photovoltaic tied to grid system is modeled in PSCAD. The model is described in details as shown in Figure 1.

\section{Modeling and Analysis of a Grid-Tied PV System}

The Photovoltaic system model consists of:
(1). PV array model

(2). Dc-link capacitor

(3). Dc-dc converter (MPPT)

(4). Three Phase inverter

(5). LCL-Filter

(6). Transformer and utility grid equivalent

\subsection{PV Array Model}

Photovoltaic is a method of generating electrical power by converting solar Radiation Into direct current electricity using semiconductors that exhibit the photovoltaic effect [1]. There are input parameters to determine PV Component in PSCAD model. First, the weather condition Includes (solar Irradiance and Temperature). In this paper the weather data used for Cairo of Egypt measured in December from The ASHRAE International Weather for Energy Calculation. Second, the default parameters that determine the Electrical Data for PV module for central inverter as shown in table1, and subsequently, the Performance of PV-Array is shown in Figure 2. In table1 the output power for one module is 650 watt and the nameplate capacity for PV Array $1 \approx 200 \mathrm{KW}$ with total number of modules 300 . 


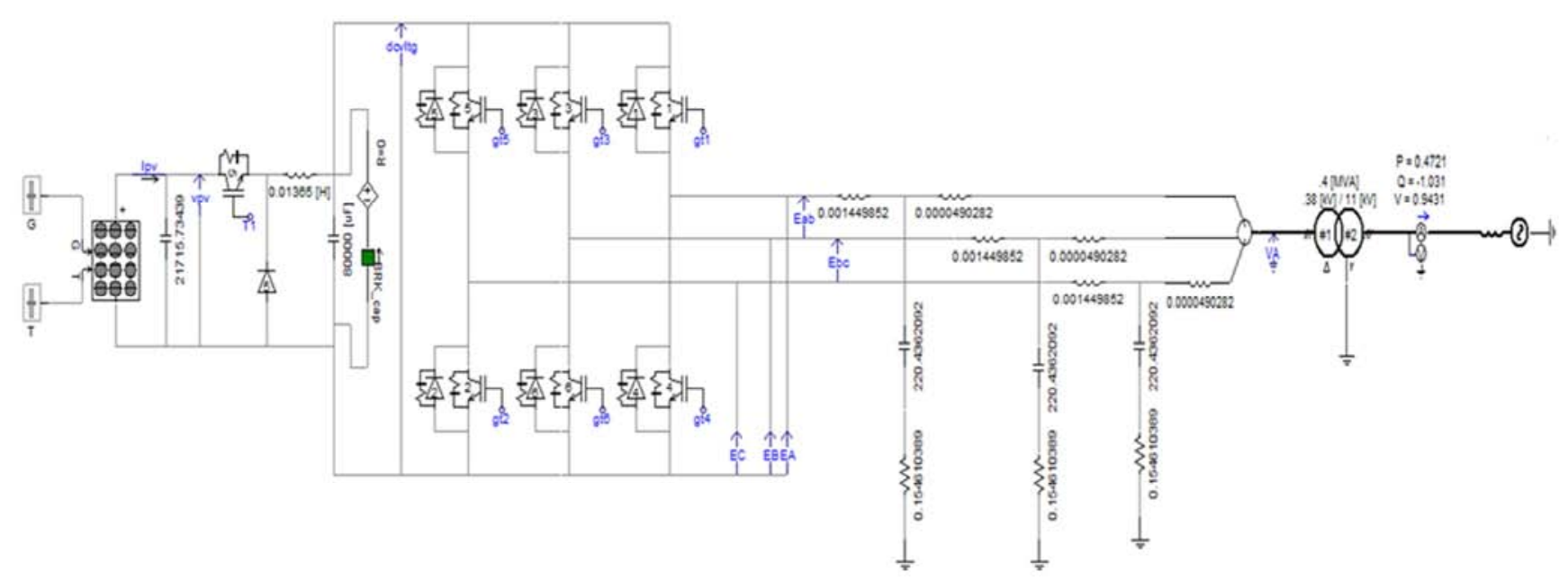

Figure 1. Photovoltaic system model tied to grid.

Table 1. PV Array configuration for Central Inverter.

\begin{tabular}{ll}
\hline PV Array configuration & \\
\hline PV array parameters & PVarray1 \\
\hline PV array name (optional) & 20 \\
\hline No. of modules connected in series / array & 15 \\
No. of module strings in parallel / array & 108 \\
No. of cells connected in series / module & 4 \\
No. of cell strings in parallel / module & 1000 \\
Reference irradiation $(\mathrm{W} / \mathrm{m} 2)$ at STC(Standard Test & \\
Condition) & 25 \\
Reference cell temperature $\left({ }^{\circ} \mathrm{c}\right)$ at STC(Standard Test & \\
Condition) & \\
PV cell parameters & 0.01 \\
Effective area / cell (m2) & 0.02 \\
Series resistance / cell ( $\Omega$ ) & 1000 \\
Shunt resistance / cell $(\Omega)$ & 1.5 \\
Diode ideality factor & 1.103 \\
Band gap energy (eV) & $1 \mathrm{e}-9$ \\
Saturation current at reference conditions / cell (A) & 2.5 \\
Short circuitcurrentat reference conditions / cell (A) & 0.001 \\
Temperature coefficient of photo current(A/K) & \\
\hline
\end{tabular}

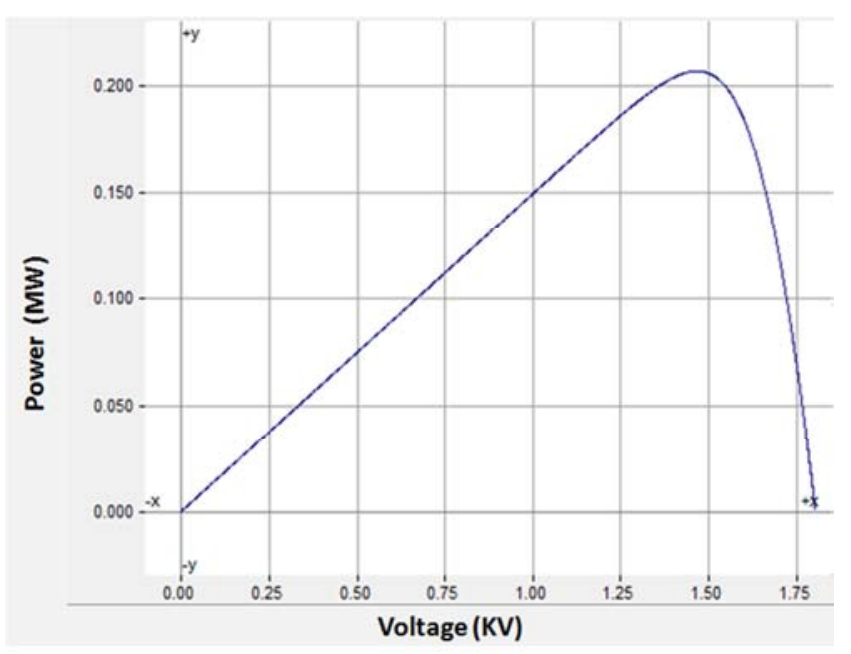

Figure 2(a). Characteristic PV array power curve at STC.

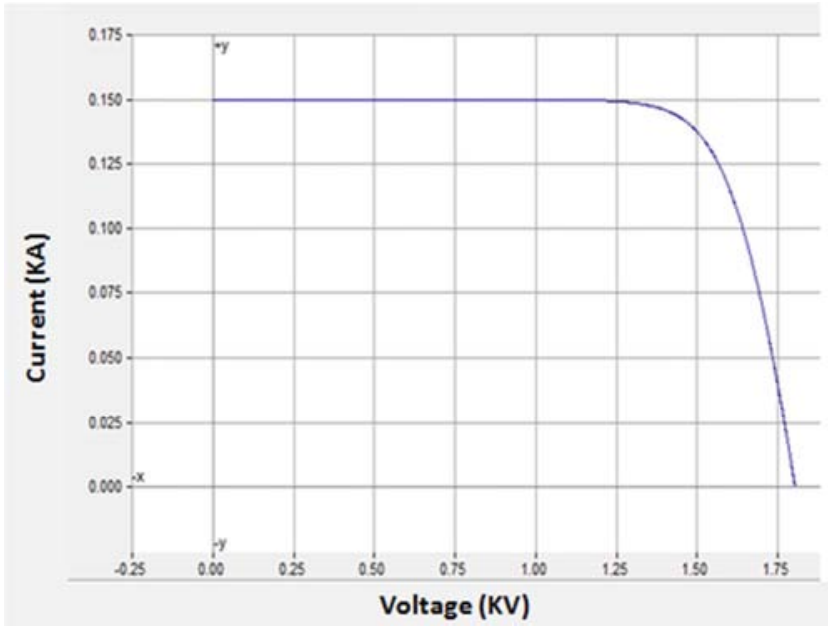

Figure 2(b). Characteristic I-V array curve at STC.

\subsection{DC-Link Capacitor}

DC link capacitor is an important component to reduce output power ripple [2]. Capacitance's equation of the DC link capacitor is

$$
C=\frac{P p v}{2 \pi f_{g} V_{p v}^{2}\left(\Delta V_{p v^{-}} \%\right)}
$$

Therefore DC-link capacitor set to $0.021715734 \mathrm{~F}$ to minimize the ripple output power [3].

\subsection{DC-DC Converter (MPPT)}

As a result of changing weather condition, the output power PV Array will vary. So Maximum Power Point Tracking (MPPT) is very important component to track the maximum power point (MPP) and obtain it for any changing weather condition and achieved high-possible PV system efficiency.

DC-DC Buck converter is used for (MPPT) by controlling the terminal voltage of PV array and this is obtained through two ways. First, creating a reference voltage. Second, creating switching signal to control IGBT Switching in DC- 
DC BUCK Converter (as shown in Figure 3) and make the terminal voltage of PV array to follow reference voltage. With regard to creating a reference voltage, there are many types of Maximum Power Point Tracking (MPPT) which responsible for creating reference Voltage such as Perturb \& Observe (P\&O) method, Incremental Conductance (INC), and Hill Climbing Method) as explained [4, 5, 6]. In This Paper Incremental Conductance is selected because the better performance of this method in regard to rapid changing weather. This method is based on the fact that the slope of power curve is zero at MPP calculating the slope of power curve, positive on the left of the MPP, and negative on the right. The instantaneous conductance (I/V) and the incremental conductance $(\Delta \mathrm{I} / \Delta \mathrm{V})$ are compared when both conductance are equal MPP is met.

Where

$$
\begin{gathered}
\mathrm{dI} / \mathrm{dV}>-\mathrm{I} / \mathrm{V} \text { (Left of Mpp) } \\
\mathrm{dI} / \mathrm{dV}<-\mathrm{I} / \mathrm{V} \text { (Right of Mpp) } \\
\mathrm{dI} / \mathrm{dV}=-\mathrm{I} / \mathrm{V} \text { (at Mpp) }
\end{gathered}
$$

Based on the previous three cases, the MPPT generates a reference voltage (Vmppt), the PSCAD model used for this stage is shown in Figure 4.

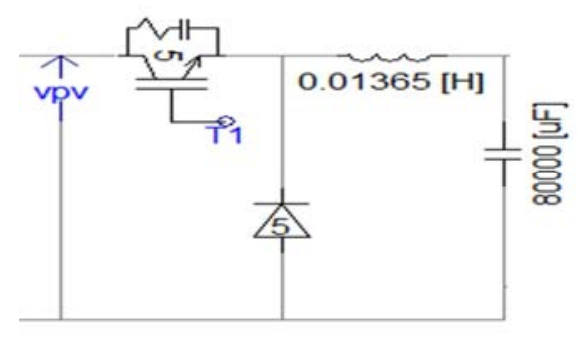

Figure 3. DC-DC Buck Converter Schematic.

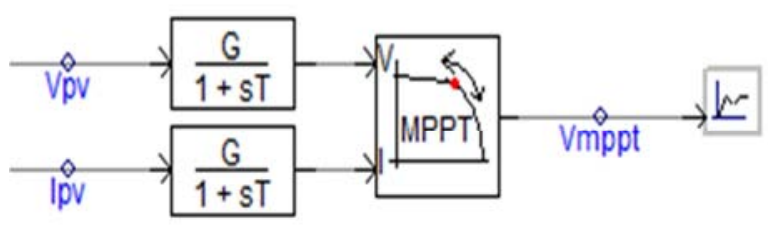

Figure 4. Maximum power point tracking model in PSCAD (Reference Voltage).

\subsection{Three Phase Inverter}

\subsubsection{PV Inverter Topology and Configuration}

The PV inverter consists of three pairs of power electronics switches (commonly implemented with an insulated gate bipolar transistor, or IGBT) [7]. As shown in Figure 1. The DC input to the inverter is applied to the top and bottom of the three parallel branches. The three phase $\mathrm{AC}$ output is produced in between the two switches in each of the three branches. [3]. PV Inverter can be categorized into four types according to configuration central, string, multi- string and Ac module [8]. This paper investigates and compare between (central and string) inverter as shown in Figure5 When all PV modules are connected to single inverter this is central. As for string inverter, there are many numbers of inverters and each one is responsible for certain number of PV modules with its own MPPT control. String inverter is the best choice when PV system subjected to shading condition because certain number of PV modules affected by shading condition In contrast Central inverter all PV modules affected by Shading and output power decrease.

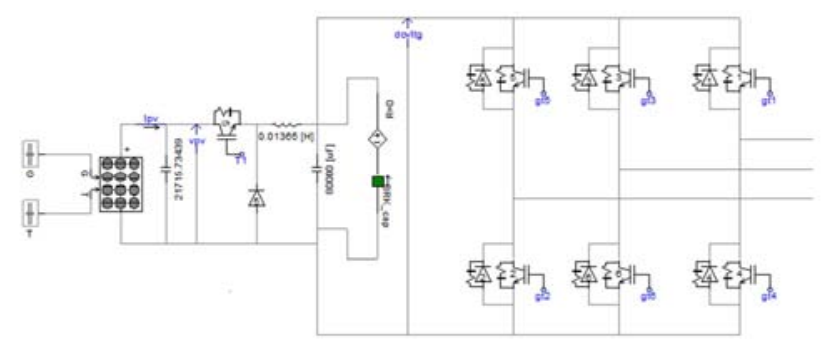

Figure 5(a). Central inverter configurations.

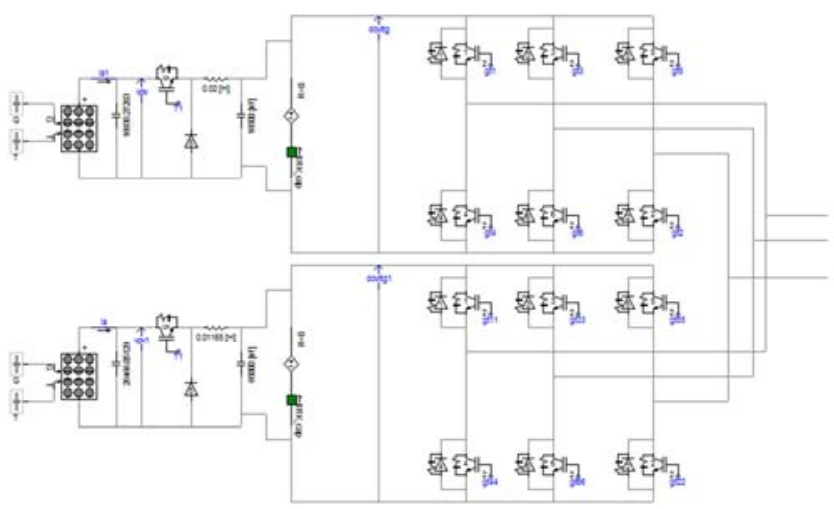

Figure 5(b). String inverter configuration.

\subsubsection{Controlling IGBT Switching}

Controlling IGBT switches range from simple to complex. In this paper two pulse width modulation methods are presented for controlling PV Inverter sinusoidal PWM and space vector PWM.

\section{Sinusoidal pulse width modulation}

Generation of the desired output voltage is achieved comparing the desired reference waveform by (modulating signal) with a high-frequency triangular 'carrier' wave with magnitude ranging between -1 and 1.there are three variables that control desired reference wave form (phase shift, The magnitude and Frequency) phase shift equal to the output of real power control modeled. With additional shifting of -120 and 120 degrees. Or $120^{\circ}$ apart from each other. The magnitude equal to output of reactive power control modeled. Real power control and reactive power control are responsible for setting dc bus at constant voltage. $5 \mathrm{KV}$ and unity power factor of inverter that produce sinusoidal voltage and current which are in phase. When reference waveform is greater than triangular carrier waveform, the output of comparator equals 1 , otherwise, 0 . So switching signals of gate $1,3,5$ are generated and by inverting them, the 
switching signals will be $4,6,2$ respectively as shown in Figure 6 , to produce the desired sinusoidal output voltage with a frequency of $50 \mathrm{~Hz}$.

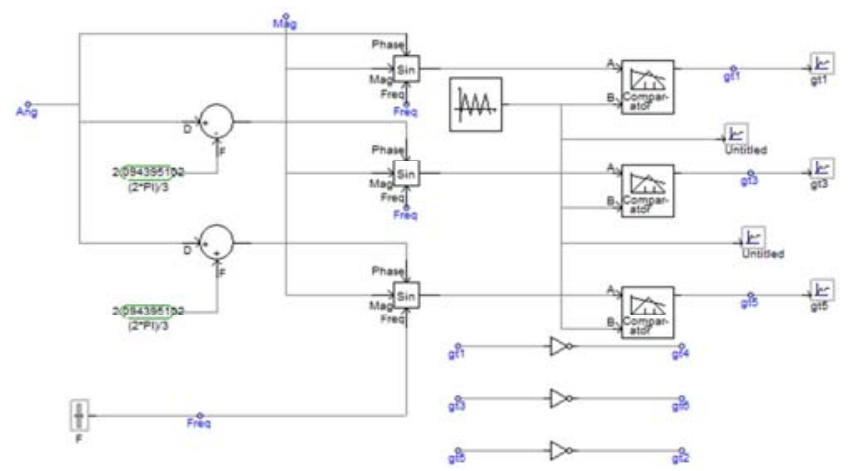

Figure 6. IGBT Gate Signals in PSCAD.

\section{Space vector modulation}

The waveform of the output voltage depends on the switching states of the switches used in the inverter. Space Vector Modulation is a modulation technique that calculates duty cycles of switches to synthesize a desired output voltage on average, without the use of a carrier waveform. The Space Vector Modulation component utilizes a two-level converter shown in Figure 1.with this converter, there are eight possible states, it is described in table 2 .By specifying a reference voltage (magnitude and phase), a voltage vector can be reconstructed on the average by using the 8 possible states of the converter.

Table 2. Switching vectors, phase and Line to Line output voltage.

\begin{tabular}{llllllllll}
\hline \multirow{2}{*}{$\begin{array}{l}\text { Voltage } \\
\text { vector }\end{array}$} & \multicolumn{3}{l}{$\begin{array}{l}\text { Switching } \\
\text { Vector }\end{array}$} & \multicolumn{4}{l}{$\begin{array}{l}\text { Line to Neutral } \\
\text { voltage }\end{array}$} & \multicolumn{5}{c}{$\begin{array}{l}\text { Line to line } \\
\text { voltage }\end{array}$} \\
\cline { 2 - 10 } & a & b & c & Van & Vbn & Ven & Vab & Vbc & Vca \\
\hline V0 & 0 & 0 & 0 & 0 & 0 & 0 & 0 & 0 & 0 \\
V1 & 1 & 0 & 0 & $2 / 3$ & $-1 / 3$ & $-1 / 3$ & 1 & 0 & -1 \\
V2 & 1 & 1 & 0 & $1 / 3$ & $1 / 3$ & $-2 / 3$ & 0 & 1 & -1 \\
V3 & 0 & 1 & 0 & $-1 / 3$ & $2 / 3$ & $-1 / 3$ & -1 & 1 & 0 \\
V4 & 0 & 1 & 1 & $-2 / 3$ & $1 / 3$ & $1 / 3$ & -1 & 0 & 1 \\
V5 & 0 & 0 & 1 & $-1 / 3$ & $-1 / 3$ & $2 / 3$ & 0 & -1 & 1 \\
V6 & 1 & 0 & 1 & $1 / 3$ & $-2 / 3$ & $1 / 3$ & 1 & -1 & 0 \\
V7 & 1 & 1 & 1 & 0 & 0 & 0 & 0 & 0 & 0 \\
\hline
\end{tabular}

Note: the respective Voltage should be Multiplied Vdc

The reconstruction is done by sampling the reference voltage at a given period Ts computing periods of time to be in certain states so that on the average, the reference voltage is attained as shown in Figure 7.

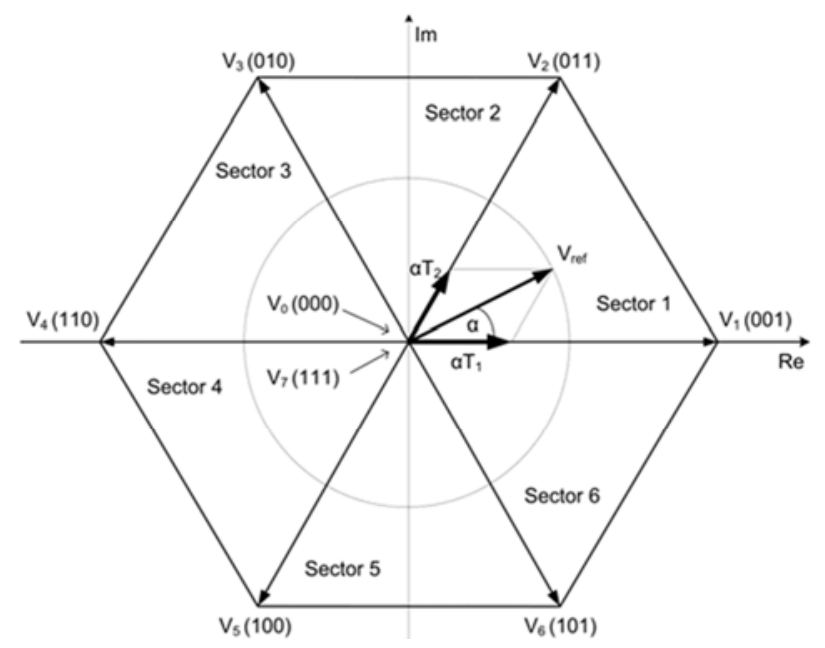

Figure 7. Space vector diagram of two-level inverter.

The calculation of the reference vector location is very important in order to calculate switching time. It is determined by utilizing phase angle of 3 phase system Clarke Transformation. (Alpha-Beta transformation) is used to calculate phase angle as shown in Figure 8. (alpha and beta) voltage are fed into Rectangular/polar Coordinate Converter to get phase angle of the reference vector and amplitude of the reference vector based on DC voltage [9].

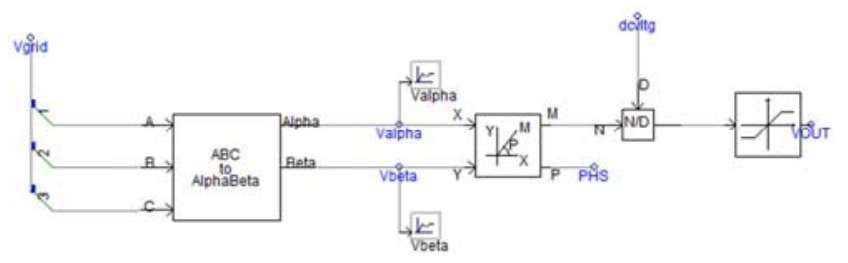

Figure 8. Phase angle and amplitude of reference vector.

The phase angle and amplitude of reference vector are input parameter to SVM component that generate switching signals gate $(1,2,3,4,5,6)$ as shown in Figure9

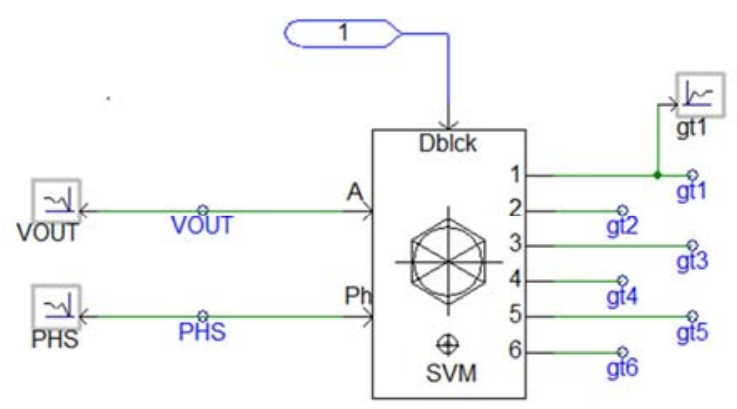

Figure 9. Calculation of firing pulses of IGBT.

\subsection{LCL Filter}

A LCL filter is often used to interconnect an inverter to the utility grid in order to filter the harmonics produced by the inverter. The LCL filter achieves a higher attenuation along with cost savings, which give the overall weight and size reduction of the components. LCL filters have been used in grid connected inverters. Where L1 is the inverter side inductor, L2 is the grid- 
side inductor; $\mathrm{Cf}$ is a capacitor with a series $\mathrm{Rf}$ damping resistor [10]. The inverter side and Grid inductor, and capacitor with series damping resistor Values for LCL filter were chosen as $1.449852 \mathrm{mH} . \quad 0.0490282 \mathrm{mH} . \quad 220.5 \mathrm{uF}, \quad 0.154610389 \Omega$ respectively. The resonant frequency is $1556.6 \mathrm{~Hz}$ that must range in-between $500 \mathrm{~Hz}$ and $1875 \mathrm{~Hz}$.

\subsection{Transformer and Utility Grid Equivalent}

A transformer is used in the PV system to step-up voltage to The utility grid system that is represented only as an equivalent $11 \mathrm{kV}$ and $50 \mathrm{~Hz}$ source behind the system inductive impedance as The power rating of the transformer is designed according to the capacity of generated power from the PV array which has a peak generation of $0.2 \mathrm{MW}$. Taken the reactive power generation and absorption into account, 0.4MVA rating is selected for the transformer. The primary and secondary of any three-phase transformer can be independent connected in either a wye $(\mathrm{Y})$ or a delta $(\mathrm{d})$. This gives a total of four possible connections for a three-phase transformer bank: 1-Wye-wye (Y-Y) 2-Wye-delta (Y -d) 3Delta-wye (D-Y) 4. Delta-Delta (d--d). In this paper the winding connection types, delta-wye is chosen for the transformer. Delta-wye connection eliminates the third order harmonic effectively. The primary side voltage winding is designed as $380 \mathrm{~V}$. Therefore, the modulation index of the inverter under normal operation is 0.44387 .

\section{Total Demand Distortion and Total Harmonic Distortion Analysis}

Sinusoidal terms (harmonics) whose frequencies are whole multiples of the fundamental frequency. In order to connect PV system to grid utility using inverter which is responsible for add harmonic distortion to grid that degrade power quality of it. For better performance of PV system connected to grid with good power quality there are standards that organize and regulate this problem. One standard is IEEE Std 929- 2000 "IEEE Recommended Practice for Utility Interface of Photovoltaic (PV) Systems" which ensures compatible operation of photovoltaic (PV) systems that are connected in parallel with the electric utility [13]. It is recommended by the previous standard that the harmonic distortion at the Point of Common Coupling (PCC), which is the point at which the PV system is tied with the grid, should comply with IEEE Std 519-1992 [11]. In this PSCAD model, PCC lies between the transformer and the grid [12]. IEEE 519-1992 standard sets specific limits for allowable current and voltage harmonics in power systems, in tables 3, 4 .

Table 3. Maximum Allowable Injected Current Harmonic.

\begin{tabular}{lc}
\hline Harmonic range & Distortion Limit(\% Rated Current) \\
\hline $\mathrm{n}<11$ & 4 \\
$11 \leq \mathrm{n}<17$ & 2 \\
$17 \leq \mathrm{n}<23$ & 1.5 \\
$23 \leq \mathrm{n}<35$ & 0.6 \\
$35 \leq \mathrm{n}$ & 0.3 \\
TDD & 5 \\
\hline
\end{tabular}

Table 4. Voltage Distortion Limits.

\begin{tabular}{lcc}
\hline PCC Voltage & Individual Harmonic Magnitudes (\%) & THDV (\%) \\
\hline $\mathrm{V} \leq 69 \mathrm{kV}$ & 3 & 5 \\
\hline
\end{tabular}

\section{Tests and Results}

In order to explain the power quality problems that occur in the PV grid-tied system, there are several tests of central and string inverters using sinusoidal pulse width modulation controlling method and space vector modulation controlling method. Then, the results are analyzed from different point of views related to types of inverter configuration and the effect of them on Power quality of grid and efficiency of system, and also related to two pulse width modulation control and effect of them on each inverter. The weather test conditions are listed as in table 5.the per unit system is performed into the PV grid-tied as in Table 6.

Table 5. Weather condition Data.

\begin{tabular}{lcc}
\hline Second & Solar Irradiance W/M2 & Cell Temperature $\left({ }^{\circ} \mathbf{C}\right)$ \\
\hline 1 & 30 & 13 \\
2 & 124 & 13 \\
3 & 261 & 14 \\
4 & 511 & 16 \\
5 & 453 & 17 \\
6 & 485 & 19 \\
7 & 483 & 20 \\
8 & 231 & 19.8 \\
9 & 102 & 20 \\
10 & 20 & 20 \\
\hline
\end{tabular}

Table 6. Per Unit Base Value.

\begin{tabular}{lll}
\hline Base & Inverter Side & Grid Side \\
\hline S base & $.2 \mathrm{MVA}$ & $.2 \mathrm{MVA}$ \\
V base & $.38 \mathrm{KV}$ & $11 \mathrm{KV}$ \\
I base & $303.86 \mathrm{~A}$ & $10.49 \mathrm{~A}$ \\
$\mathrm{Z}$ base & $0.722 \mathrm{Ohm}$ & $605 \mathrm{Ohm}$ \\
\hline
\end{tabular}

\subsection{Central Inverters by Using SPWM Controlling Method.}

\subsubsection{Total Demand Distortion}

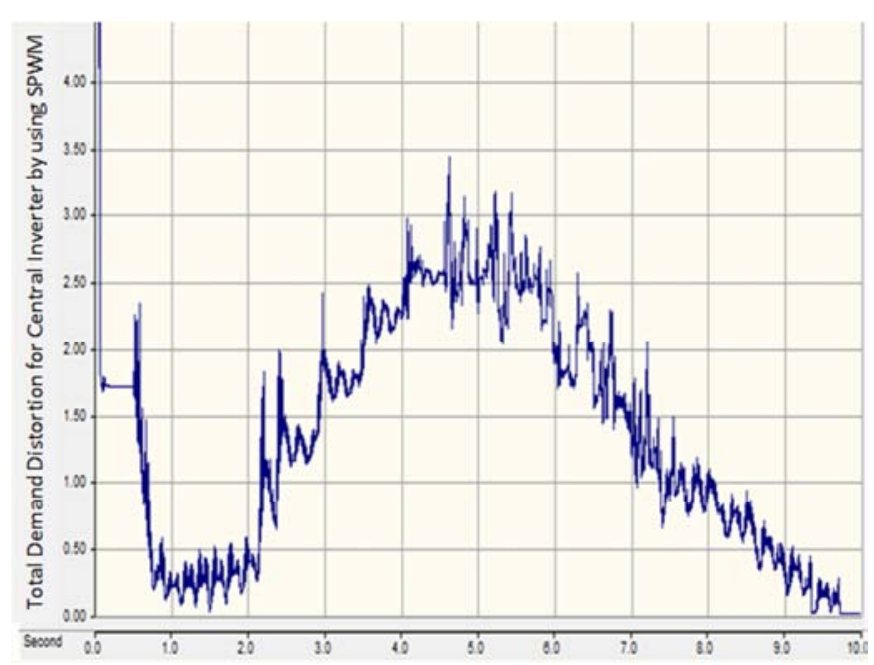

Figure 10. TDD \% of the current at PCC of central inverter using SPWM. 


\subsubsection{Total Harmonic Distortion}

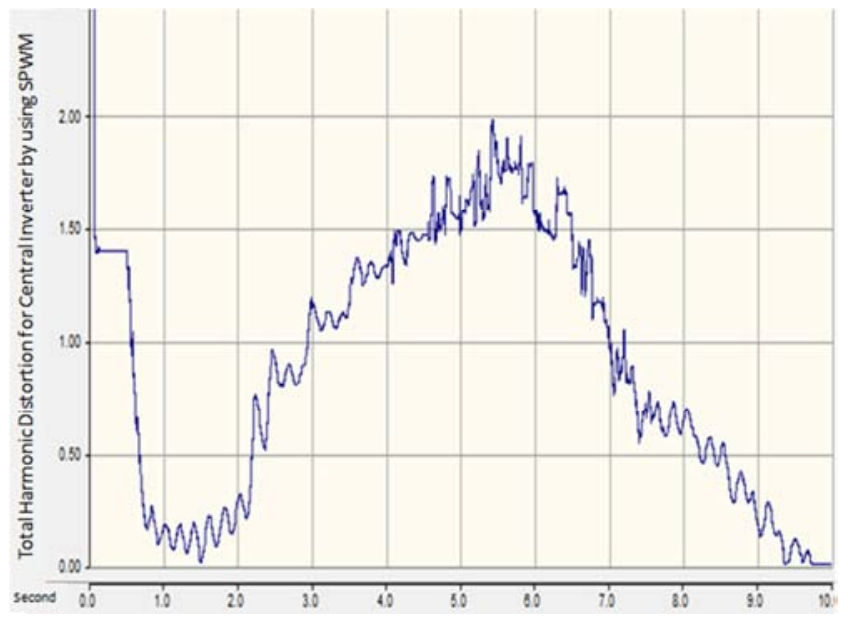

Figure 11. THD \% of the Voltage at PCC of central inverter using SPWM.

\subsubsection{RMS Output Voltage}

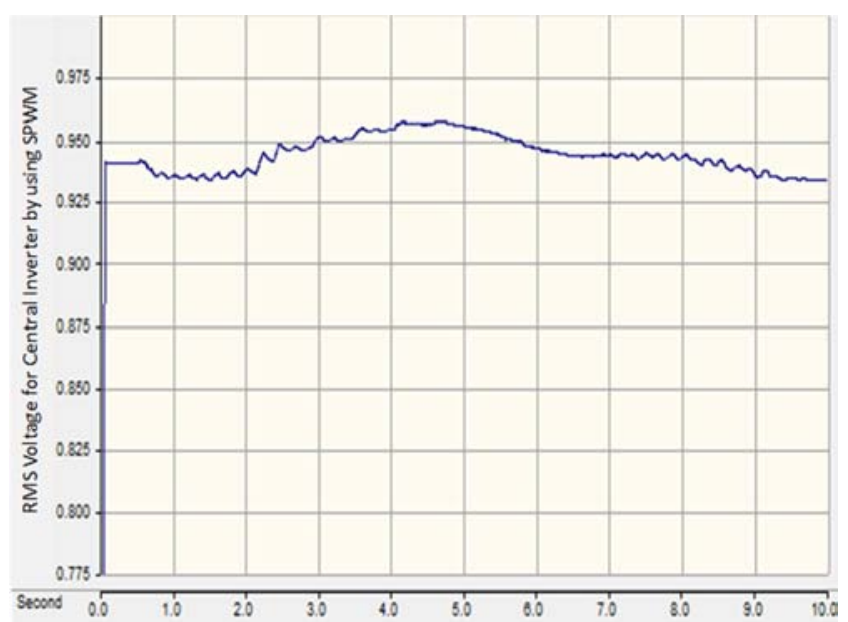

Figure 12. RMS-output voltage of central inverter using SPWM.

\subsection{String Inverter by Using SPWM Controlling Method}

\subsubsection{Total Demand Distortion}

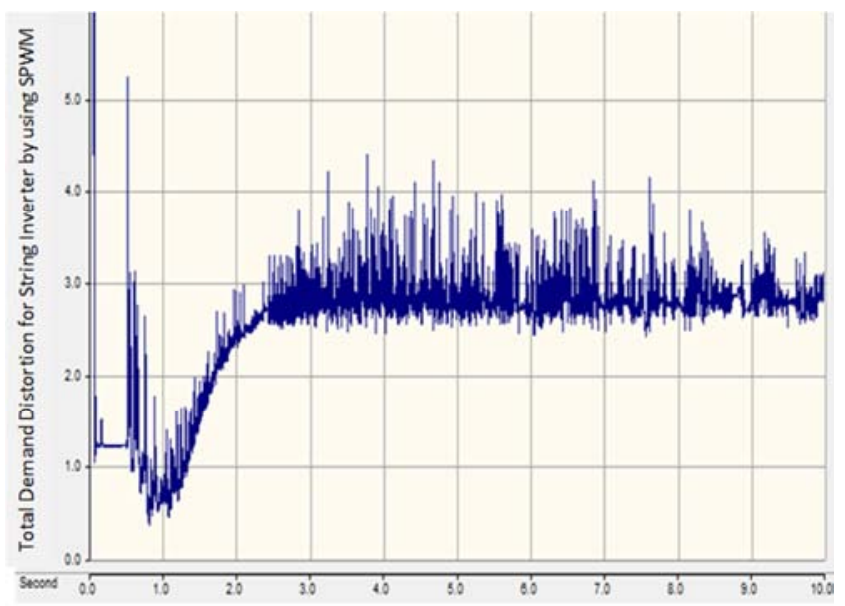

Figure 13. TDD \% of the current at PCC of string inverter using SPWM.

\subsubsection{Total Harmonic Distortion}

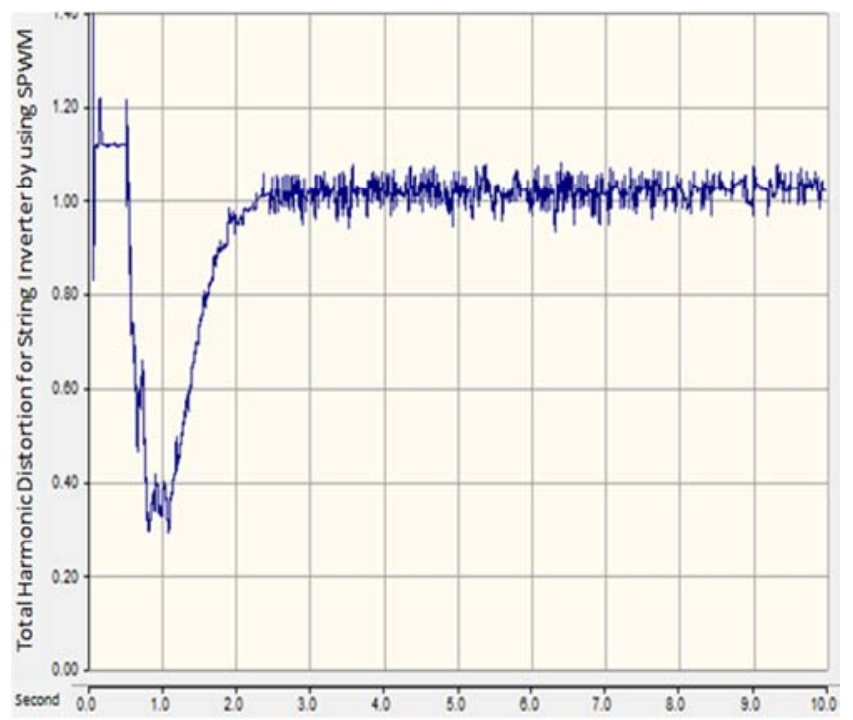

Figure 14. THD \% of the Voltage at PCC of string inverter using SPWM.

Table 7. TDD, THD \% generated by the PV inverter by using controlling method.

\begin{tabular}{llll}
\hline $\begin{array}{l}\text { Harmonic } \\
\text { Analysis }\end{array}$ & Central Inverter & String Inverter & $\begin{array}{l}\text { Harmonic } \\
\text { Limit \% Rated }\end{array}$ \\
\hline TDD \% & 0.021274958 & 1.759647869 & 5 \\
THD \% & 0.012394533 & 1.023940213 & 5 \\
\hline
\end{tabular}

Table 8. Individual current Harmonic amplitude for central and string inverter by using SPWM controlling method.

\begin{tabular}{|c|c|c|c|}
\hline $\mathbf{N}$ & SPWM-CENTRAL & $\begin{array}{l}\text { SPWM- } \\
\text { STRING }\end{array}$ & $\begin{array}{l}\text { Max-Injected } \\
\text { Current Harmonic }\end{array}$ \\
\hline 2 & 0.000196339 & 0.464956 & \multirow{10}{*}{ 4\% Rated Current } \\
\hline 3 & 0.0104291 & 0.927124 & \\
\hline 4 & 0.000138039 & 0.278023 & \\
\hline 5 & 0.00754386 & 0.173191 & \\
\hline 6 & 0.000101248 & 0.187959 & \\
\hline 7 & 0.00595807 & 0.484302 & \\
\hline 8 & 7.13342E-05 & 0.042019 & \\
\hline 9 & 0.00565036 & 0.194121 & \\
\hline 10 & $6.04249 \mathrm{E}-05$ & 0.127907 & \\
\hline 11 & 0.00612665 & 0.833151 & \\
\hline $\mathrm{N}$ & SPWM-CENTRAL & $\begin{array}{l}\text { SPWM- } \\
\text { STRING }\end{array}$ & $\begin{array}{l}\text { Max-Injected Current } \\
\text { Harmonic }\end{array}$ \\
\hline 12 & $3.71714 \mathrm{E}-05$ & 0.230231 & \multirow{6}{*}{$2 \%$ Rated Current } \\
\hline 13 & 0.0111273 & 0.168755 & \\
\hline 14 & 0.000033876 & 0.177599 & \\
\hline 15 & 0.00525366 & 0.65922 & \\
\hline 16 & 3.96393E-05 & 0.0436422 & \\
\hline 17 & 0.00359119 & 0.439795 & \\
\hline $\mathrm{N}$ & SPWM-CENTRAL & $\begin{array}{l}\text { SPWM- } \\
\text { STRING }\end{array}$ & $\begin{array}{l}\text { Max-Injected Current } \\
\text { Harmonic }\end{array}$ \\
\hline 18 & 0.000020525 & 0.0418504 & \multirow{6}{*}{ 1.5\%Rated Current } \\
\hline 19 & 0.00107362 & 0.149081 & \\
\hline 20 & $2.11103 \mathrm{E}-05$ & 0.0245769 & \\
\hline 21 & 0.00268154 & 0.207248 & \\
\hline 22 & 1.71927E-05 & 0.0267883 & \\
\hline 23 & 0.00248125 & 0.251452 & \\
\hline $\mathrm{N}$ & SPWM-CENTRAL & $\begin{array}{l}\text { SPWM- } \\
\text { STRING }\end{array}$ & $\begin{array}{l}\text { Max-Injected Current } \\
\text { Harmonic }\end{array}$ \\
\hline 24 & $1.40898 \mathrm{E}-05$ & 0.0106306 & \multirow{4}{*}{$0.6 \%$ Rated Current } \\
\hline 25 & 0.000129301 & 0.0423872 & \\
\hline 26 & $1.4309 \mathrm{E}-05$ & 0.0161131 & \\
\hline 27 & 0.0013004 & 0.103127 & \\
\hline
\end{tabular}




\begin{tabular}{llll}
\hline N & SPWM-CENTRAL & $\begin{array}{l}\text { SPWM- } \\
\text { STRING }\end{array}$ & $\begin{array}{l}\text { Max-Injected } \\
\text { Current Harmonic }\end{array}$ \\
\hline 28 & $2.31221 \mathrm{E}-05$ & 0.0176166 & \\
29 & 0.000498823 & 0.0691544 & \\
30 & $3.42318 \mathrm{E}-05$ & 0.0214951 & \\
31 & 0.00106396 & 0.0272178 & \\
\hline
\end{tabular}

\subsubsection{RMS Output Voltage}

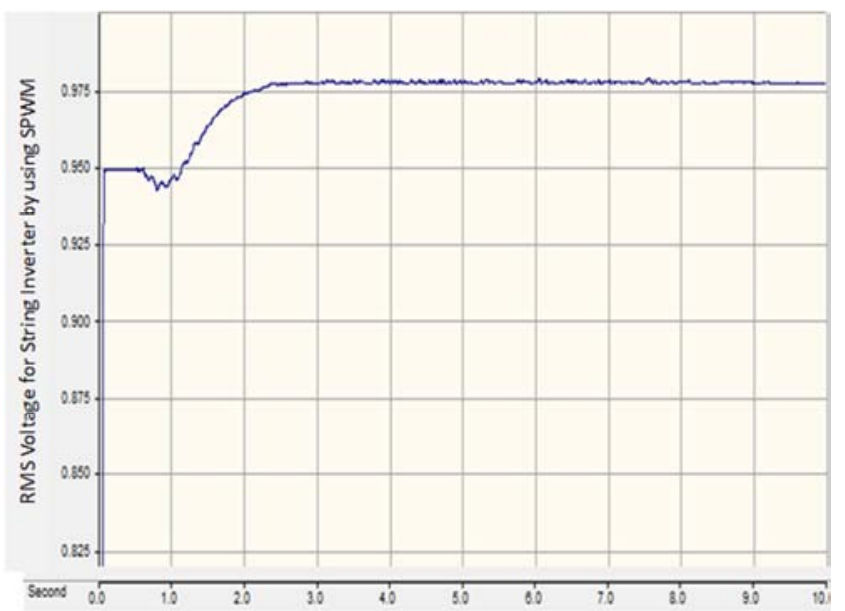

Figure 15. RMS-output voltage of string inverter using SPWM.

In Figure $(10,11,13$, and 14) are shown the TDD of the current and THD of the voltage in phase A at PCC for Central and String Inverter by using SPWM. It is observed that TDD \&THD of central inverters are less than string inverter and this is rational because Central Inverter has only one Converter and String Inverter has more than one. But String inverter has good performance than central inverter as shown in Figure $(12,15)$ that Illustrates RMS output voltage of string inverter higher than central inverter. TDD, THD, individual current and voltage harmonic amplitude for central and string inverter are shown in tables 7, 8, 9 .

Table 9. Individual Voltage Harmonic amplitude for central and string inverter by using SPWM controlling method.

\begin{tabular}{llll}
\hline N & $\begin{array}{l}\text { SPWM- } \\
\text { CENTRAL }\end{array}$ & $\begin{array}{l}\text { SPWM- } \\
\text { STRING }\end{array}$ & $\begin{array}{c}\text { Voltage Distortion Limits } \\
\text { Expressed in \% }\end{array}$ \\
\hline 2 & $6.76854 \mathrm{E}-06$ & 0.0449653 & \\
3 & 0.0015428 & 0.149453 & \\
4 & $3.31947 \mathrm{E}-06$ & 0.0593501 & \\
5 & 0.00191129 & 0.0355659 & \\
6 & $5.0607 \mathrm{E}-06$ & 0.0528414 & \\
7 & 0.00216813 & 0.17414 & \\
8 & $8.21054 \mathrm{E}-06$ & 0.029436 & \\
9 & 0.00269236 & 0.0964424 & Individual Harmonic \\
10 & $1.91603 \mathrm{E}-06$ & 0.0623966 & Magnitudes 3 (\%) \\
11 & 0.00344767 & 0.482802 & \\
12 & $1.32968 \mathrm{E}-05$ & 0.137679 & \\
13 & 0.00746331 & 0.101871 & \\
14 & $1.99317 \mathrm{E}-05$ & 0.141199 & \\
15 & 0.00410965 & 0.526567 & \\
16 & $3.96944 \mathrm{E}-06$ & 0.0297216 & \\
17 & 0.00268993 & 0.398964 & \\
18 & $5.85594 \mathrm{E}-06$ & 0.0265899 & \\
\hline
\end{tabular}

\begin{tabular}{lllc}
\hline N & $\begin{array}{l}\text { SPWM- } \\
\text { CENTRAL }\end{array}$ & $\begin{array}{l}\text { SPWM- } \\
\text { STRING }\end{array}$ & $\begin{array}{c}\text { Voltage Distortion Limits } \\
\text { Expressed in \% }\end{array}$ \\
\hline 19 & 0.00100371 & 0.156345 & \\
20 & $3.4386 \mathrm{E}-06$ & 0.0309234 & \\
21 & 0.00288404 & 0.223658 & \\
22 & $1.34015 \mathrm{E}-06$ & 0.019583 & \\
23 & 0.00299269 & 0.294109 & \\
24 & $2.9897 \mathrm{E}-06$ & 0.00559115 & \\
25 & 0.000271815 & 0.0628117 & \\
26 & $2.11736 \mathrm{E}-06$ & 0.00397948 & \\
27 & 0.0019115 & 0.181058 & \\
28 & $1.3749 \mathrm{E}-06$ & 0.00550588 & \\
29 & 0.00102835 & 0.0597491 & \\
30 & $1.5553 \mathrm{E}-06$ & 0.00413493 & \\
31 & 0.000995663 & 0.0422173 & \\
\hline
\end{tabular}

\subsection{Central Inverter by Using SVM Controlling Method}

\subsubsection{Total Demand Distortion}

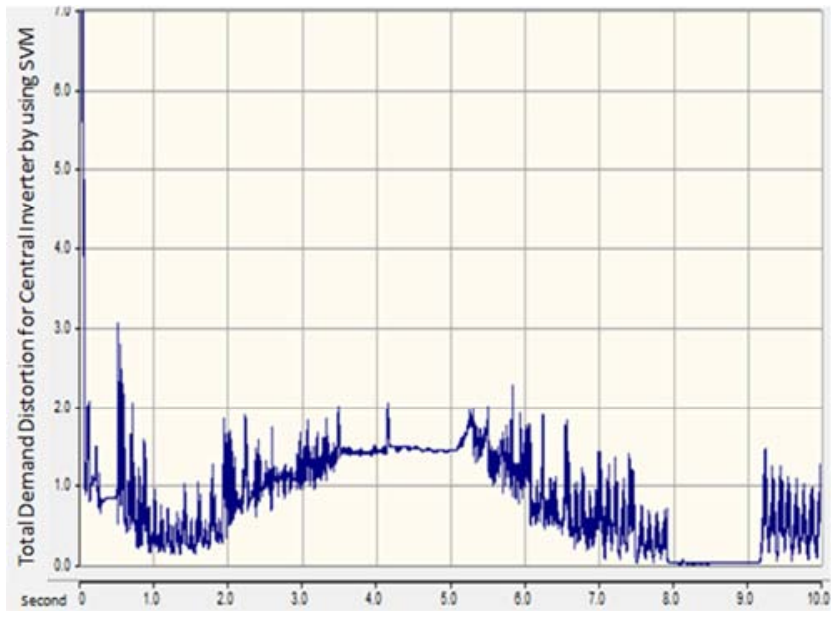

Figure 16. TDD \% of the current at PCC of central using SVM.

\subsubsection{Total Harmonic Distortion}

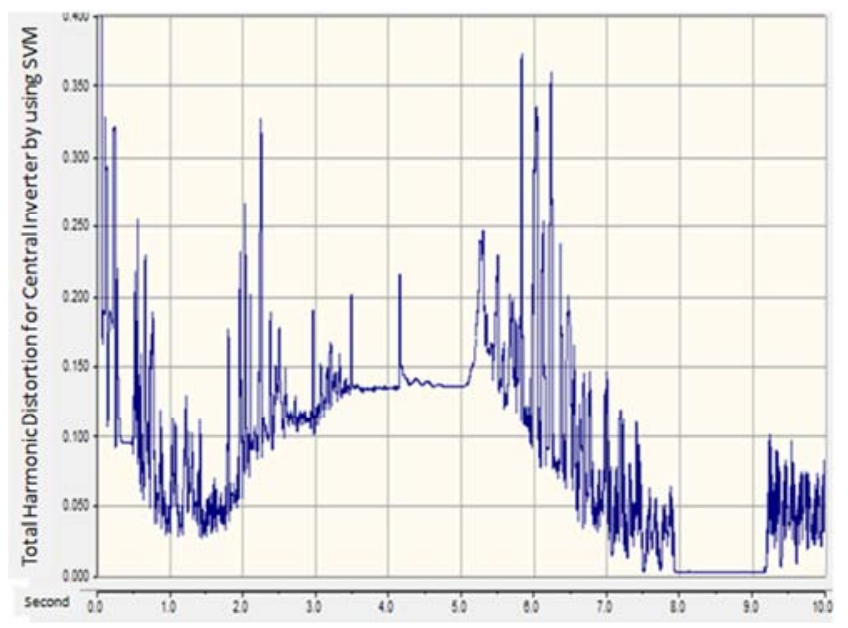

Figure 17. THD \% of the current at PCC of central inverter using SVM. 


\subsubsection{RMS Output Voltage}

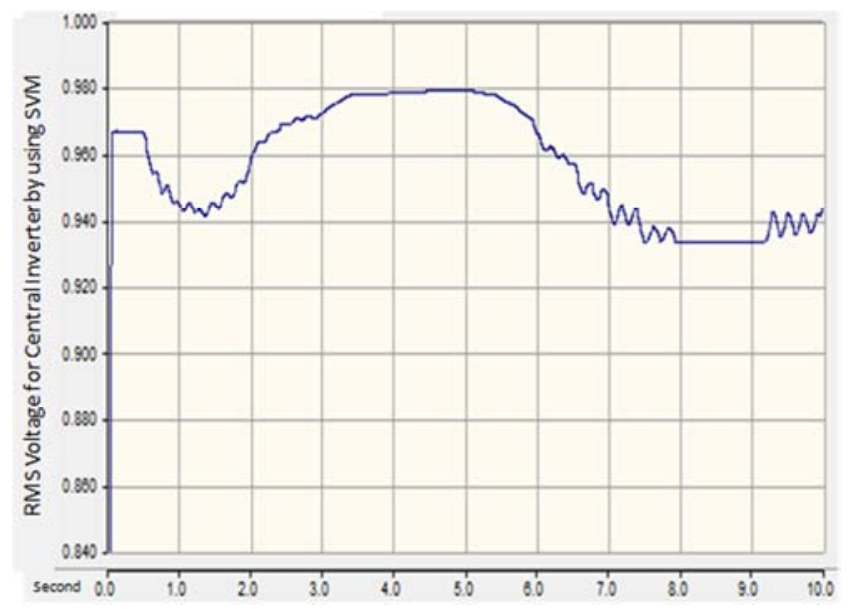

Figure 18. RMS-output voltage of central inverter Using SVM.

\subsection{String Inverter Using SVM Controlling Method}

\subsubsection{Total Demand Distortion}

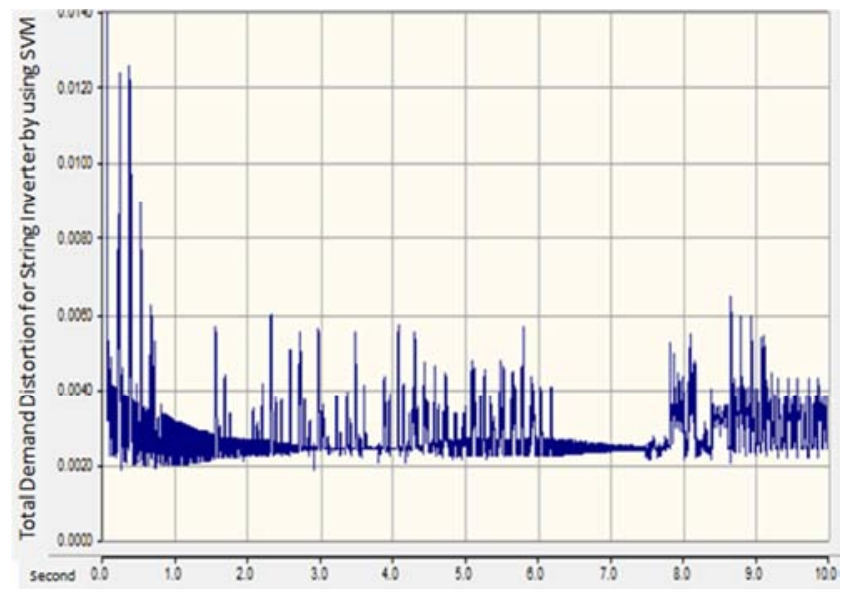

Figure 19. TDD \% of the current at PCC of string inverter using SVM.

\subsubsection{Total Harmonic Distortion}

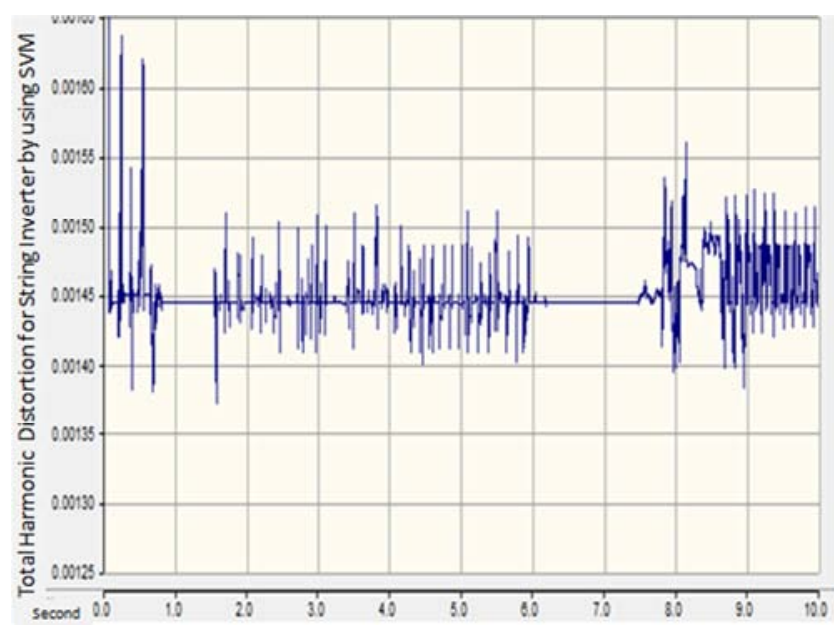

Figure 20. THD \% of the current at PCC of string inverter using SVM.

\subsubsection{RMS Output Voltage}

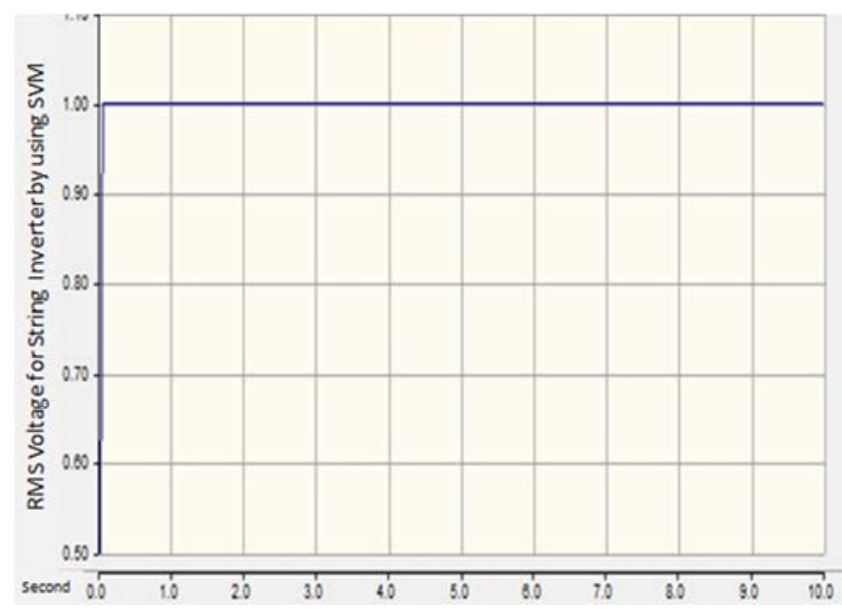

Figure 21. RMS-output of string inverter using $S V M$.

Comparing between Central and string Inverter Using Space Vector Modulation proving that central Inverter less than string inverter in total harmonic distortion and total demand distortion and string inverter better performance than central under effect of changing weather condition as shown in Figure $(16,19,17,20,18$ and 21). TDD, THD, individual current and voltage harmonic amplitude for central and string inverter by using SVM are shown in tables10, 11, 12.

Table 10. TDD, THD \% generated by the Central and string inverter by using $S V M$.

\begin{tabular}{lccc}
\hline $\begin{array}{l}\text { Harmonic } \\
\text { Analysis }\end{array}$ & $\begin{array}{c}\text { Central } \\
\text { Inverter }\end{array}$ & $\begin{array}{c}\text { String } \\
\text { Inverter }\end{array}$ & $\begin{array}{c}\text { Harmonic Limit \% } \\
\text { Rated }\end{array}$ \\
\hline TDD \% & 0.014443484 & 0.628365269 & 5 \\
THD \% & 0.003013343 & 0.001239393 & 5 \\
\hline
\end{tabular}

Table 11. Individual current Harmonic amplitude for central and string inverter by using SVM controlling method.

\begin{tabular}{llcl}
\hline $\mathbf{N}$ & $\begin{array}{c}\text { SVM- } \\
\text { CENTRAL }\end{array}$ & $\begin{array}{c}\text { SVM- } \\
\text { STRING }\end{array}$ & $\begin{array}{c}\text { Voltage Distortion } \\
\text { Limits Expressed } \\
\text { in \% }\end{array}$ \\
\hline 2 & 0.00119879 & $6.30925 \mathrm{E}-05$ & \\
3 & 0.000941861 & 0.000031568 & \\
4 & 0.000694784 & $3.38963 \mathrm{E}-05$ & \\
5 & 0.00153511 & $3.87501 \mathrm{E}-05$ & \\
6 & 0.000488041 & $3.27517 \mathrm{E}-05$ & \\
7 & 0.000630571 & $4.54625 \mathrm{E}-05$ & \\
8 & 0.000315466 & $3.39036 \mathrm{E}-05$ & \\
9 & 0.000292779 & $2.61145 \mathrm{E}-05$ & \\
10 & 0.000292534 & $5.02554 \mathrm{E}-05$ & \\
11 & 0.000431019 & $2.83759 \mathrm{E}-05$ & Individual \\
12 & 0.000158031 & $2.83759 \mathrm{E}-05$ & Harmonic \\
13 & $4.52978 \mathrm{E}-05$ & 0.000015437 & Magnitudes 3(\%) \\
14 & 0.00017007 & $1.88039 \mathrm{E}-05$ & \\
15 & 0.000560715 & 0.000749944 & \\
16 & 0.000139603 & $2.13753 \mathrm{E}-05$ & \\
17 & 0.000451652 & $7.45104 \mathrm{E}-05$ & \\
18 & $8.44129 \mathrm{E}-05$ & $2.05893 \mathrm{E}-05$ & \\
19 & 0.000245678 & $7.59637 \mathrm{E}-05$ & \\
20 & $4.99388 \mathrm{E}-05$ & $3.03815 \mathrm{E}-05$ & \\
21 & 0.000083282 & $5.03409 \mathrm{E}-05$ & \\
22 & $2.41689 \mathrm{E}-05$ & 0.000016666 & \\
23 & $6.96761 \mathrm{E}-05$ & 0.000013922 & \\
\hline & & & \\
\hline
\end{tabular}




\begin{tabular}{cccc}
\hline $\mathbf{N}$ & $\begin{array}{c}\text { SVM- } \\
\text { CENTRAL }\end{array}$ & $\begin{array}{c}\text { SVM- } \\
\text { STRING }\end{array}$ & $\begin{array}{c}\text { Voltage Distortion } \\
\text { Limits Expressed } \\
\text { in \% }\end{array}$ \\
\hline 24 & 0.000183946 & 0.000071326 & \\
25 & $6.96761 \mathrm{E}-05$ & $1.61737 \mathrm{E}-05$ & \\
26 & 0.000103165 & $6.02483 \mathrm{E}-05$ & \\
27 & $5.57949 \mathrm{E}-05$ & $4.74481 \mathrm{E}-05$ & \\
28 & $3.99348 \mathrm{E}-05$ & $7.96461 \mathrm{E}-05$ & \\
29 & $1.45047 \mathrm{E}-05$ & $2.84478 \mathrm{E}-05$ & \\
30 & $2.55844 \mathrm{E}-05$ & 0.000026998 & \\
31 & 0.000959026 & 0.000959597 & \\
\hline
\end{tabular}

Table 12. Individual Voltage Harmonic amplitude for central and string inverter by using $S V M$.

\begin{tabular}{|c|c|c|c|}
\hline $\mathbf{N}$ & $\begin{array}{c}\text { SPWM- } \\
\text { CENTRAL }\end{array}$ & $\begin{array}{l}\text { SPWM- } \\
\text { STRING }\end{array}$ & $\begin{array}{c}\text { Max-Injected Current } \\
\text { Harmonic }\end{array}$ \\
\hline 2 & 0.000196339 & 0.464956 & \multirow{10}{*}{$4 \%$ Rated Current } \\
\hline 3 & 0.0104291 & 0.927124 & \\
\hline 4 & 0.000138039 & 0.278023 & \\
\hline 5 & 0.00754386 & 0.173191 & \\
\hline 6 & 0.000101248 & 0.187959 & \\
\hline 7 & 0.00595807 & 0.484302 & \\
\hline 8 & 7.13342E-05 & 0.042019 & \\
\hline 9 & 0.00565036 & 0.194121 & \\
\hline 10 & $6.04249 \mathrm{E}-05$ & 0.127907 & \\
\hline 11 & 0.00612665 & 0.833151 & \\
\hline $\mathrm{N}$ & $\begin{array}{l}\text { SPWM- } \\
\text { CENTRAL }\end{array}$ & $\begin{array}{l}\text { SPWM- } \\
\text { STRING }\end{array}$ & \multirow[t]{3}{*}{$\begin{array}{l}\text { Max-Injected Current } \\
\text { Harmonic }\end{array}$} \\
\hline 12 & $3.71714 \mathrm{E}-05$ & 0.230231 & \\
\hline 13 & 0.0111273 & 0.168755 & \\
\hline 14 & 0.000033876 & 0.177599 & \multirow{4}{*}{$2 \%$ Rated Current } \\
\hline 15 & 0.00525366 & 0.65922 & \\
\hline 16 & 3.96393E-05 & 0.0436422 & \\
\hline 17 & 0.00359119 & 0.439795 & \\
\hline $\mathrm{N}$ & $\begin{array}{l}\text { SPWM- } \\
\text { CENTRAL }\end{array}$ & $\begin{array}{l}\text { SPWM- } \\
\text { STRING }\end{array}$ & \multirow[t]{3}{*}{$\begin{array}{l}\text { Max-Injected Current } \\
\text { Harmonic }\end{array}$} \\
\hline 18 & 0.000020525 & 0.0418504 & \\
\hline 19 & 0.00107362 & 0.149081 & \\
\hline 20 & 2.11103E-05 & 0.0245769 & \multirow{4}{*}{ 1.5\%Rated Current } \\
\hline 21 & 0.00268154 & 0.207248 & \\
\hline 22 & $1.71927 \mathrm{E}-05$ & 0.0267883 & \\
\hline 23 & 0.00248125 & 0.251452 & \\
\hline $\mathrm{N}$ & $\begin{array}{l}\text { SPWM- } \\
\text { CENTRAL }\end{array}$ & $\begin{array}{l}\text { SPWM- } \\
\text { STRING }\end{array}$ & \multirow[t]{9}{*}{$\begin{array}{l}\text { Max-Injected Current } \\
\text { Harmonic }\end{array}$} \\
\hline 24 & $1.40898 \mathrm{E}-05$ & 0.0106306 & \\
\hline 25 & 0.000129301 & 0.0423872 & \\
\hline 26 & $1.4309 \mathrm{E}-05$ & 0.0161131 & \\
\hline 27 & 0.0013004 & 0.103127 & \\
\hline 28 & $2.31221 \mathrm{E}-05$ & 0.0176166 & \\
\hline 29 & 0.000498823 & 0.0691544 & \\
\hline 30 & $3.42318 \mathrm{E}-05$ & 0.0214951 & \\
\hline 31 & 0.00106396 & 0.0272178 & \\
\hline
\end{tabular}

\section{Conclusion}

This paper focuses on the impact of PV system tied to grid on power quality problem. This paper investigates $\mathrm{PV}$ inverter configuration such as Central and string with twopulse width modulation methods (SPWM-SVM) and the effect of them on power quality from view point of Harmonic. Also, the effect of two types selected of inverter on PV system efficiency is determined. Lastly analysis of Total Demand Distortion and Total Harmonic Distortion at PCC by using FFT block and the value obtained were compared with limit specified through IEEE- std. the results proved that TDD and THD of central inverter less than string Inverter in both cases of using SPWM, SVM Controlling method and string inverter is better performance than central when subjected to shadow effect. Also, TDD and THD of Inverter using SVM less than Inverter using SPWM.

\section{References}

[1] Zheng Zhao,Jih-Sheng Lai, Wensong Yu, Kathleen Meehan,Virgilio A. Centeno,Douglas J. Nelson,"High Efficiency Single-stage Grid-tied PV Inverter for Renewable Energy System" Virginia Polytechnic Institute and State University April 20, 2012.

[2] Kow Ken Weng, Wong Yee Wan, Rajparthiban Kumar Rajkumar, Rajprasad Kumar Rajkumar, "Power Quality Analysis for PV Grid Connected System UsingPSCAD/EMTDC"INTERNATIONAL JOURNAL of RENEWABLE ENERGY RESEARCH Kow Ken Weng et al., Vol.5, No.1, 2015.

[3] Benjamin Anders Johnson, Dr. Taufik, Dr. Ahmad Nafisi,Dr. Ali Shaban, "Modeling and Analysis of a PV Grid-Tied Smart Inverter's Support Functions" The Faculty of California State University, San Luis Obispo.

[4] Vladimir cuk, Paulo F. Ribeiro, JosephF.GCobben, Wil L.Kling, Fridi. R.Isleiffsson, henrikW.Binder Nis Martensen,Afshinsamadi, and lennartsoder ",Consideration on the modling of photovoltaic system for grid Impact studies " 1 st international work shop on integration of solar power into power system,Aarhus,Denmark,24 Octobor 2011.

[5] SantaClara, "ALTA Devices solar panel receives NREL verification of $23.5 \%$ efficiency" press release, February6, 2012-available-at

hppt://www.roederjahnson.com/RJDocs/alnrelverification 0212.html.as seen on 21-8-2012.

[6] Carl Franzen, "Height solar panel efficiency Achieved"TPMidealab, FEBRUARY7, 2012 Available-at http://idealab.talkingpointsmemo.com/2012/02/highest-solarpanel-efficiency -achieved.php as seen On15-09-2012.

[7] E. Muljadi, M. Singh, and V. GevorgianNational Renewable Energy Laboratory Prepared under Task No.SS13.2020.

[8] Farahan-mahood, "improving the photovoltaic in Power factory" "KTH-Electrical Engineering Stockholm, Sweden 2011.XR-EE-ES2012:017.

[9] Lütfüsaribulut, mehmet, tümay"Robustsvm technique to minimize the effects of unbalanced voltage disturbance" Çukurova-university Department of Electrical and electronic engineering /Adana/turkey.

[10] A. Reznik, M.GodoySimões, Ahmed Al-Durra, S. M. Muyeen. Colorado School of Mines, EECS Dept., Golden, CO, USA"LCL Filter Design and Performance Analysis for Grid Interconnected Systems" Petroleum Institute, Electrical Engineering Department, Abu Dhabi, UAE. 
[11] IEEE Recommended Practices and Requirements for Harmonic Control in Electrical Power Systems, IEEE Standard 519, 1992.

[12] Abdulrahman Y. Kalbat, Member, IEEE "PSCAD Simulation of Grid-Tied Photovoltaic Systems and Total Harmonic
Distortion Analysis"2013 3rd International Conference on Electric Power and Energy Conversion Systems).

[13] IEEE Recommended Practice for Utility Interface of Photovoltaic (PV) Systems, IEEE Standard, 929-2000. 